\title{
GAYA BAHASA PADA CATATAN NAJWA DI TRANS 7 EDISI BULAN JULI - AGUSTUS 2019
}

\author{
Moch Yadi \\ Institusi/Fakultas Sastra Indonesia Universitas Pamulang
}

Alamat Surel/mbeyadi23@gmail.com

\begin{abstract}
ABSTRAK
Penelitian ini bertujuan untuk (1). Mendeskripsikan jenis gaya bahasa berdasarkan struktur kalimat dan (2). Mendeskripsikan jenis gaya bahasa berdasarkan langsung dan tidaknya makna pada Catatan Najwa di Trans 7 Edisi Bulan Juli - Agustus 2019. Teori yang digunakan adalah teori diksi dan gaya bahasa. Objek dalam penelitian ini adalah sebuah catatan acara talkshow. Data penelitian dikumpulkan dengan menggunakan metode simak bebas libat cakap dan dilanjutkan dengan teknik catat, yang kemudian dianalisis dengan metode agih dan teknik lanjutannya menggunakan pilah unsur penentu. Dari hasil penelitian, diperoleh simpulan: (1). Terdapat tiga jenis gaya bahasa berdasarkan struktur kalimat pada Catatan Najwa di Trans 7 edisi bulan Juli - Agustus 2019. Ketiga jenis gaya bahasa tersebut yaitu paralelisme, antitesis, dan repetisi. (2). Terdapat sepuluh jenis gaya bahasa berdasarkan langsung dan tidaknya makna pada Catatan Najwa di Trans 7 edisi bulan JuliAgustus 2019. Sepuluh jenis gaya bahasa tersebut yaitu aliterasi, asonansi, pleonasme dan tautologi, erotesis atau pertanyaan retoris, hiperbol, persamaan atau simile, personifikasi, sinekdoke, metonimia, dan sarkasme. Kata kunci: Gaya Bahasa, Stilistika, Catatan Najwa
\end{abstract}

\section{PENDAHULUAN}

Gaya bahasa adalah cara khas seseorang menggunakan bahasa untuk mengungkapkan gagasan dan emosinya, sehingga dalam penggunaan bahasa tersebut menimbulkan konotasi dan nilai keindahan tertentu, khususnya dalam dunia karangan. Baik itu dalam bentuk lisan maupun tulisan.

Setiap pengarang ingin menampilkan nilai-nilai yang lebih tinggi dan mampu menafsirkan tentang kehidupan melalui bahasa sebagai alat komunikasi, sehingga memunculkan interaksi antara pengarang dengan pembaca atau pendengar. Dalam menciptakan sebuah karya, pengarang mempunyai gaya bahasa khas tersendiri sebagai identitasnya. Kekhasan inilah yang membedakan pengarang yang satu dengan lainnya. Salah satunya adalah Najwa Shihab dalam Catatan Najwa.

Catatan Najwa, sebuah penutup acara yang berisikan narasi dari seorang jurnalis senior yang mampu membuat pembaca dan pendengarnya terkesima dan terpancing untuk mencerna dan memikirkan lebih seksama. Bukan hanya sekedar goresan kata-kata, melainkan sikap dan kejelian dalam mengolah kata dan rasa. Setiap barisan kalimatnya mengandung sindiran dengan gaya bahasa dan makna yang tersirat. Selain itu, gaya bahasa pada

Catatan Najwa berperan mempertegas dan memperindah kalimat sehingga indah dan menarik bagi pendengar dan pembaca. Penggunaan gaya bahasa menjadi faktor penting oleh Najwa Shihab dan berhasil menarik para pendengar dan pembacanya. Akan tetapi, penggunaan gaya bahasa dalam Catatan Najwa akan sulit dipahami oleh pendengar atau pembaca yang kurang memiliki kompetensi berbahasa. Banyaknya pandangan mengenai gaya bahasa, membuat penulis ingin melakukan penelitian tentang gaya bahasa yang terdapat pada Catatan Najwa. Yang akan ditekankan disini yaitu cara melihat jenis 
gaya bahasa apakah yang terdapat pada Catatan Najwa tersebut dengan menggunakan kajian stilistika. Hal ini dapat dilihat dari Catatan Najwa di bawah ini.

Catatan Najwa dengan tema “Kejutan 2019” yang tayang pada tanggal 3 Juli 2019 di Televisi:

Karena syarat pencalonan yang relatif sangat berat

Kandidat Capres-Cawapres menjadi begitu ketat

Tak banyak kemungkinan kandidat yang akan maju

Maksimal hanya tiga pasang saja yang melaju

Jangan heran tarik ulur terus menerus terjadi

Belum ada satupun pasangan yang telah resmi

Masing-masing kubu saling intip dan saling kunci

Sembari terus beraksi tawar menawar posisi

Entah apa yang dibicarakan dalam lobi

Hanya segelintir elite yang ikut negosiasi

Rasanya sekarang sulit bicara yang serba ideal

Karena menang kalah memang rumus politik elektoral

Publik hanya berharap yang terbaiklah yang dimajukan

Bukan cuma elektabilitas dan bagi-bagi jabatan

Karena kandidat seharusnya bukan hasil dagang eceran

Pemimpin bukanlah tahu bulat yang digoreng dadakan

Berdasarkan Catatan Najwa di atas, terdapat sindiran dengan menggunakan gaya bahasa yang khas. Jika dilihat dari segi non bahasa, gaya bahasa pada Catatan Najwa itu berdasarkan subjek, yakni subjek yang menjadi pokok pembicaraan dalam sebuah karangan dapat mempengaruhi pula gaya bahasa sebuah karangan (Keraf, 2009:116). Jika dilihat dari segi bahasa, gaya bahasa pada Catatan Najwa itu cenderung berdasarkan struktur kalimat, dan langsung tidaknya makna. Sebagaimana diketahui, bahwa stilistika adalah ilmu tentang bahasa dan gaya bahasa, serta penggunaannya. Maka dari itu penulis tertarik untuk mengkaji gaya bahasa karena gaya bahasa hanya digunakan oleh orang yang memiliki keterampilan berbahasa secara efektif.

Penelitian ini perlu dilakukan karena untuk memberikan informasi dan menambah pengetahuan pembaca dalam bidang ilmu kebahasaan khususnya mengenai gaya bahasa, baik dalam bentuk lisan maupun tulisan, salah satunya yang terdapat pada Catatan Najwa.

\section{TEORI DAN METODOLOGI}

Metode penelitian pada dasarnya merupakan cara ilmiah untuk mendapatkan data dengan tujuan dan kegunaan tertentu (Sugiyono, 2016:2). Berdasarkan hal tersebut terdapat empat kata kunci yang perlu diperhatikan, yaitu: cara ilmiah, data, tujuan, dan kegunaan.

Dalam hal ini penulis melakukan penelitian menggunakan metode deskriptif kualitatif. Karena penelitian ini mendeskripsikan data yang berupa kalimat atau tuturan yang terdapat pada Catatan Najwa di Trans 7 yang di dalamnya mengandung gaya bahasa. Sehingga penelitian ini diidentifikasi sebagai penelitian deskriptif kualitatif. 


\section{TEMUAN DAN PEMBAHASAN}

\subsection{Gaya Bahasa Berdasarkan Struktur Kalimat}

Berikut ini penulis akan mendeskripsikan jenis gaya bahasa berdasarkan struktur kalimat yang terdapat pada Catatan Najwa di Trans 7 Edisi Bulan Juli — Agustus 2019.

Table 4.1

Jenis gaya bahasa berdasarkan struktur kalimat yang terdapat pada Catatan Najwa di Trans 7 Edisi Bulan Juli - Agustus 2019.

$\begin{array}{llll}\text { No. } & \text { Jenis Gaya Bahasa } & \text { Jumlah } \\ \text { 1. } & \text { Paralelisme } & 3 & \\ \text { 2. } & \text { Antitesis } & 1 & \\ \text { 3. } & \text { Repetisi } & 3 & \end{array}$

Pada subbab 4.1 ini akan dijelaskan tiga jenis gaya bahasa berdasarkan struktur kalimat yang terdapat pada Catatan Najwa di Trans 7 Edisi Bulan Juli - Agustus 2019, yaitu gaya bahasa paralelisme, antitesis, dan repetisi. Penjelasannya sebagai berikut:

\subsubsection{Paralelisme}

Paralelisme adalah semacam gaya bahasa yang berusaha mencapai kesejajaran dalam pemakaian kata-kata atau frasa-frasa yang menduduki fungsi yang sama dalam bentuk gramatikal yang sama. Kesejajaran tersebut dapat pula berbentuk anak kalimat yang bergantung pada sebuah induk kalimat yang sama. Gaya ini lahir dari struktur kalimat yang berimbang (Keraf. 2009:126).

Jenis gaya bahasa paralelisme yang terdapat pada Catatan Najwa dapat dilihat di bawah ini.

Data 1.

Tentang kebenaran yang terpojok sendirian

Perihal keadilan yang diperam kesunyian

Data 2.

Hukum akhirnya menjelma dokumen berdebu

Karena tak berbunyi laksana orang gagu

Data (1) dan (2) diambil dari penggalan kalimat pada Catatan Najwa dengan tema "Sebelah Mata Novel Baswedan". Pada data (1), terdiri dari dua kalimat yang berbentuk kalimat tunggal, karena masing-masing terdiri satu klausa, yaitu kalimat pertama "Tentang kebenaran yang terpojok sendirian" dan kalimat kedua "Perihal keadilan yang diperam kesunyian". Dalam data (1), terdapat gaya bahasa paralelisme. Kesejajaran itu terlihat pada bagian kalimat "Tentang kebenaran" dan "Perihal keadilan". Hal ini menggambarkan bahwa kebenaran sejajar dengan keadilan dalam hal hukum. Pada data (2), berbentuk kalimat majemuk bertingkat, ditandai dengan konjungsi subordinatif "karena". Dalam data (2), terdapat gaya bahasa paralelisme. Kesejajaran itu terlihat pada bagian kalimat "menjelma dokumen 
berdebu" dengan "tak berbunyi laksana orang gagu" yang menggambarkan kesejajaran jika hukum tidak ditegakkan.

Data 3.

Hukum diciptakan agar tak ada kesewenangan

Supaya kita semua tak bertindak melampaui kepatutan

Data (3) diambil dari penggalan kalimat pada Catatan Najwa dengan tema "Kasta Hukuman". Pada data (3), berbentuk kalimat mejemuk bertingkat, ditandai dengan konjungsi "supaya". Dalam data (3), terdapat gaya bahasa paralelisme. Terlihat pada bagian kalimat "tak ada kesewenangan" dengan "tak bertindak melampaui kepatutan" yang menggambarkan kesejajaran dalam hal peraturan.

\subsubsection{Antitesis}

Antitesis adalah sebuah gaya bahasa yang mengandung gagasan-gagasan yang bertentangan, dengan mempergunakan kata-kata atau kelompok kata yang berlawanan. Gaya ini timbul dari kalimat yang berimbang (Keraf, 2009:126).

Jenis gaya bahasa antitesis yang terdapat pada Catatan Najwa dapat dilihat di bawah ini.

Data 4.

Di hadapan hukum semua harus setara

Jangan di pengadilan hasilnya malah berbeda

Data (4) diambil dari penggalan kalimat pada Catatan Najwa dengan tema "Kasta Hukuman". Pada data (4), terdiri dari dua kalimat. Kalimat pertama berbentuk kalimat bebas, karena ujarannya lengkap tanpa bantuan kalimat lain yang menjelaskannya, yaitu "Di hadapan hukum semua harus setara". Kalimat kedua berbentuk kalimat terikat, yaitu "Jangan di pengadilan hasilnya malah berbeda". Bukti keterikatan kalimat kedua dari kalimat pertama adalah adanya penanda anaforis - nya pada kata hasilnya, yang merujuk pada kata hukum dalam kalimat pertama. Dalam data (4), terdapat gaya bahasa antitesis. Gagasan yang bertentangan itu tergambar pada bagian kalimat "harus setara" dan "malah berbeda" tentang penegakan hukum.

\subsubsection{Repetisi}

Adalah perulangan bunyi, suku kata, kata, atau bagian kalimat yang sangat penting untuk memberi tekanan dalam sebuah konteks yang sesuai (Keraf, 2016:127). Dalam bagian ini hanya akan dibicarakan repetisi yang berbentuk kata atau frasa atau klausa. Karena nilainya dianggap tinggi, maka dalam oratori timbullah bermacam-macam variasi repetisi seperti (Epizeuksis, Tautotes, Anafora, 
Epistrofa, Simploke, Mesodiplosis, Epanalepsis, Anadiplosis). Repetisi, seperti halnya dengan paralelisme dan antitesis, lahir dari kalimat yang berimbang (Keraf, 2009:127).

Data di bawah ini termasuk repetisi Mesodiplosis, yakni repetisi di tengah baris-baris atau beberapa kalimat berurutan. Jenis gaya bahasa Mesodiplosis yang terdapat pada Catatan Najwa dapat dilihat di bawah ini.

Data 5.

Mereka bertanggung jawab dengan bekerja

Kita bertanggung jawab dengan awasi mereka

Data (5) diambil dari penggalan kalimat pada Catatan Najwa dengan tema "Penghuni Baru DPR". Pada data (5), terdiri dari dua kalimat yang berbentuk kalimat tunggal, karena masing-masing terdiri satu klausa, yaitu kalimat pertama "Mereka bertanggung jawab dengan bekerja" dan kalimat kedua "Kita bertanggung jawab dengan awasi mereka". Dalam data (5), terdapat gaya bahasa repetisi mesodiplosis. Perulangan bagian kalimat yang dianggap penting untuk memberi tekanan di tengah baris-baris itu tergambar pada bagian kalimat "bertanggung jawab", sebagai bentuk penegasan dalam hal pengawasan kinerja DPR.

Data 6.

PLN tak bisa lepas tanggung jawab begitu saja

Para petingginya tak bisa buang badan seenaknya

Data (6) diambil dari penggalan kalimat pada Catatan Najwa dengan tema "Hidup Mati Listrik". Pada data (6), terdiri dari dua kalimat yang berbentuk kalimat tunggal, karena masing-masing terdiri satu klausa, yaitu kalimat pertama "PLN tak bisa lepas tanggung jawab begitu saja" dan kalimat kedua "Para petingginya tak bisa buang badan seenaknya". Dalam data (6), terdapat gaya bahasa repetisi mesodiplosis. Perulangan bagian kalimat yang dianggap penting untuk memberi tekanan di tengah baris-baris itu tergambar pada bagian kalimat "tak bisa", sebagai bentuk penegasan untuk hal tanggung jawab kinerja para pegawai PLN pada saat mengalami masalah.

Data 7.

Jangan sampai hukum malah tumpul ke atas

Pada yang lemah hukum justru menjadi buas 
Data (7) diambil dari penggalan kalimat pada Catatan Najwa dengan tema "Kasta Hukuman". Pada data (7), berbentuk kalimat tunggal, karena terdiri satu klausa, yaitu "Jangan sampai hukum malah tumpul ke atas, pada yang lemah hukum justru menjadi buas". Dalam data (7), terdapat gaya bahasa repetisi mesodiplosis. Perulangan bagian kalimat yang dianggap penting untuk memberi tekanan di tengah baris-baris itu tergambar pada kata "hukum", sebagai bentuk penegasan untuk perihal penegakan hukum.

\subsection{Gaya Bahasa Berdasarkan Langsung dan Tidaknya Makna}

Berikut ini penulis akan mendeskripsikan jenis gaya bahasa berdasarkan langsung tidaknya makna yang terdapat pada Catatan Najwa di Trans 7 Edisi Bulan Juli - Agustus 2019.

Table 4.2

Jenis gaya bahasa berdasarkan langsung tidaknya makna yang terdapat pada Catatan Najwa di Trans 7 Edisi Bulan Juli - Agustus 2019.

No. Jenis Gaya Bahasa

1. Aliterasi

2. Asonansi

3. Pleonasme \& Tautologi

4. Erotesis atau Pertanyaan Retoris

5. Hiperbol

6. Persamaan atau Simile

7. Personifikasi

8. Sinekdoke

9. Metonimia

10. Sarkasme
Jumlah

16

10

3

1

9

1

1

1

11

5

Pada subbab 4.2 ini akan dijelaskan sepuluh jenis gaya bahasa berdasarkan langsung dan tidaknya makna yang terdapat pada Catatan Najwa di Trans 7 Edisi Bulan Juli - Agustus 2019, yaitu gaya bahasa aliterasi, asonansi, pleonasme \& tautologi, erotesis atau pertanyaan retoris, hiperbol, persamaan atau simile, personifikasi, sinekdoke, metonimia, dan sarkasme. Penjelasannya sebagai berikut: 


\subsubsection{Aliterasi}

Aliterasi adalah semacam gaya bahasa yang berwujud perulangan konsonan yang sama. Biasanya dipergunakan dalam puisi, kadang-kadang dalam prosa, untuk perhiasan atau untuk penekanan (Keraf, 2009:130).

Jenis gaya bahasa aliterasi yang terdapat pada Catatan Najwa dapat dilihat di bawah ini.

Data 8.

Karena syarat pencalonan yang relatif sangat berat

Kandidat Capres-Cawapres menjadi begitu ketat

Data (8) diambil dari penggalan kalimat pada Catatan Najwa dengan tema "Kejutan 2019". Pada data (8), berbentuk kalimat majemuk bertingkat, ditandai dengan konjungsi subordinatif "karena". Dalam data (8), terdapat gaya bahasa aliterasi. Perulangan konsonan yang sama tergambar pada huruf konsonan " $\mathrm{t}$ " pada kata syarat, relatif, sangat, berat, kandidat, begitu, dan ketat.

Data 9.

Wajar jika pesimisme menyeruak dengan hebat

Cerita tak enak kadung lekat kepada wakil rakyat

Data (9) diambil dari penggalan kalimat pada Catatan Najwa dengan tema "Penghuni Baru DPR". Pada data (9), berbentuk kalimat tunggal, karena hanya terdiri satu klausa, yaitu kalimat pertama "Wajar jika pesimisme menyeruak dengan hebat, cerita tak enak kadung lekat kepada wakil rakyat". Dalam data (9), terdapat gaya bahasa aliterasi. Perulangan konsonan yang sama tergambar pada huruf konsonan "t" pada kata hebat, cerita, tak, lekat, dan rakyat.

Data 10.

Itulah hakikat dari partisipasi publik

Terlibat tak boleh hanya di bilik

Karena politik bekerja setiap detik

Data (10) diambil dari penggalan kalimat pada Catatan Najwa dengan tema "Penghuni Baru DPR". Pada data (10), berbentuk kalimat majemuk bertingkat, ditandai dengan konjungsi subordinatif "karena". Dalam data (10), terdapat gaya bahasa aliterasi. Perulangan konsonan yang sama tergambar pada huruf konsonan "k" pada kata hakikat, publik, tak, bilik, karena, politik, bekerja, dan detik. 
Data 11.

Polarisasi bukan sekadar urusan para elit

Akar rumput pun sudah ikut-ikutan terbelit

Data (11) diambil dari penggalan kalimat pada Catatan Najwa dengan tema "Gerbang JokowiPrabowo: Siapa hendak turut?". Pada data (11), terdiri dari dua kalimat yang berbentuk kalimat nonverbal, karena predikatnya bukan kata atau frasa verbal, ditandai dengan kata advervial "bukan" dan "sudah". Dalam data (11), terdapat gaya bahasa aliterasi. Perulangan konsonan yang sama tergambar pada huruf konsonan "r" pada kata polarisasi, sekedar, urusan, para, akar, rumput, dan terbelit.

Data 12.

Hentikan cemooh dan beragam bentuk penghinaan

Kritiklah untuk urusan genting yang diperlukan

Suasana damai dibutuhkan demi persatuan

Berpelukan bukan untuk bagi-bagi kekuasaan

Tak boleh ada kekuasaan yang tidak diawasi

Lakukan pengawasan tanpa agitasi dan provokasi

Data (12) diambil dari penggalan kalimat pada Catatan Najwa dengan tema "Gerbang JokowiPrabowo: Siapa hendak turut?". Pada data (12), terdiri dari enam kalimat yang berbentuk kalimat tunggal, karena masing-masing terdiri satu klausa, yaitu kalimat pertama "Hentikan cemooh dan beragam bentuk penghinaan". Kalimat kedua "Kritiklah untuk urusan genting yang diperlukan". Kalimat ketiga "Suasana damai dibutuhkan demi persatuan". Kalimat keempat "Berpelukan bukan untuk bagi-bagi jabatan". Kalimat kelima "Tak boleh ada kekuasaan yang tidak diawasi". Kalimat keenam "Lakukan pengawasan tanpa agitasi dan provokasi". Dalam data (12), terdapat gaya bahasa aliterasi. Perulangan konsonan yang sama tergambar pada huruf konsonan " $\mathrm{n}$ " pada kata hentikan, dan, bentuk, penghinaan, untuk, urusan, genting, diperlukan, suasana, dibutuhkan, persatuan, berpelukan, bukan, untuk, kekuasaan, lakukan, pengawasan, dan tanpa.

Data 13.

Pengungkapan yang dihalangi tabir kasak-kusuk

Kita selalu mengulang kisah-kisah yang buruk 
Data (13) diambil dari penggalan kalimat pada Catatan Najwa dengan tema "Sebelah Mata Novel Baswedan". Pada data (13), terdiri dari dua kalimat yang berbentuk kalimat tunggal, karena masing-masing terdiri dari satu klausa, yaitu kalimat pertama "Pengungkapan yang dihalangi tabir kasak-kusuk" dan kalimat kedua "Kita selalu mengulang kisah-kisah yang buruk". Dalam data (13), terdapat gaya bahasa aliterasi. Perulangan konsonan yang sama tergambar pada huruf konsonan "k" pada kata pengungkapan, kasak-kusuk, kita, kisah-kisah, dan buruk.

Data 14.

Tentang kebenaran yang terpojok sendirian

Perihal keadilan yang diperam kesunyian

Data (14) diambil dari penggalan kalimat pada Catatan Najwa dengan tema "Sebelah Mata Novel Baswedan". Pada data (14), terdiri dari dua kalimat yang berbentuk kalimat tunggal, karena masing-masing terdiri satu klausa, yaitu kalimat pertama "Tentang kebenaran yang terpojok sendirian" dan kalimat kedua "Perihal keadilan yang diperam kesunyian". Dalam data (14), terdapat gaya bahasa aliterasi. Perulangan konsonan yang sama tergambar pada huruf konsonan " $\mathrm{n}$ " pada kata tentang, kebenaran, sendirian, keadilan, dan kesunyian.

Data 15.

Kebebasan yang menindas orang lain bukanlah kemerdekaan

Demokrasi mensyaratkan kesetimbangan hak dan kewajiban

Data (15) diambil dari penggalan kalimat pada Catatan Najwa dengan tema "FPI: Simalakama Ormas". Pada data (15), terdiri dari dua kalimat yang berbentuk kalimat tunggal, karena masing-masing terdiri satu klausa, yaitu kalimat pertama "Kebebasan yang menindas orang lain bukanlah kemerdekaan" dan kalimat kedua "Demokrasi mensyaratkan kesetimbangan hak dan kewajiban". Dalam data (15), terdapat gaya bahasa aliterasi. Perulangan konsonan yang sama tergambar pada huruf konsonan " $\mathrm{n}$ " pada kata kebebasan, menindas, lain, bukanlah, kemerdekaan, mensyaratkan, kesetimbangan, dan, kewajiban.

Data 16.

Apalagi untuk kebutuhan yang mendasar

Memenuhinya mesti dengan ikhtiar yang besar 
Data (16) diambil dari penggalan kalimat pada Catatan Najwa dengan tema "Hidup Mati Listrik". Pada data (16), terdiri dari satu kalimat yang berbentuk kalimat tunggal, karena hanya terdiri dari satu klausa, yaitu "Apalagi untuk kebutuhan yang mendasar, Memenuhinya mesti dengan ikhtiar yang besar". Dalam data (16), terdapat gaya bahasa aliterasi. Perulangan konsonan yang sama tergambar pada huruf konsonan " $r$ " pada kata mendasar, ikhtiar, dan besar.

Data 17.

Sudah terlalu lama listrik dikelola serampangan

Hajat hidup rakyat bukan urusan sembarangan

Data (17) diambil dari penggalan kalimat pada Catatan Najwa dengan tema "Hidup Mati Listrik". Pada data (17), terdiri dari dua kalimat yang berbentuk kalimat tunggal, karena masing-masing terdiri dari satu klausa. Yaitu kalimat pertama "Sudah terlalu lama listrik dikelola serampangan" dan kalimat kedua "Hajat hidup rakyat bukan urusan sembarangan". Dalam data (17), terdapat gaya bahasa aliterasi. Perulangan konsonan yang sama tergambar pada huruf konsonan " $n$ " pada kata serampangan, bukan, urusan, dan sembarangan.

Data 18.

Diskriminasi tidak pantas diberi tempat

Sudah sepatutnya rasisme juga dibabat

Data (18) diambil dari penggalan kalimat pada Catatan Najwa dengan tema "Nyala Papua". Pada data (18), terdiri dari dua kalimat yang berbentuk kalimat tunggal, karena masing-masing terdiri dari satu klausa, yaitu kalimat pertama "Diskriminasi tidak pantas diberi tempat" dan kalimat kedua "Sudah sepatutnya rasisme juga dibabat". Dalam data (18), terdapat gaya bahasa aliterasi. Perulangan konsonan yang sama tergambar pada huruf konsonan " $\mathrm{t}$ " pada kata tidak, pantas, tempat, sepatutnya, dan dibabat.

Data 19.

Jika memang ingin Indonesia tetap utuh

Tak boleh ada kejahatan yang tak tersentuh

Data (19) diambil dari penggalan kalimat pada Catatan Najwa dengan tema "Nyala Papua". Pada data (19), berbentuk kalimat tunggal, karena terdiri dari satu klausa, yaitu "Jika memang ingin Indonesia tetap utuh, tak boleh ada kejahatan yang tak tersentuh". Dalam data (19), terdapat gaya bahasa 
aliterasi. Perulangan konsonan yang sama tergambar pada huruf konsonan "h" pada kata utuh, boleh, kejahatan, dan tersentuh.

Data 20.

Mari berbicara dengan cara yang bermartabat

Sebelum terlambat dengan luka penuh bebat

Data (20) diambil dari penggalan kalimat pada Catatan Najwa dengan tema "Nyala Papua". Pada data (20), berbentuk kalimat tunggal, karena terdiri dari satu klausa, yaitu "Mari berbicara dengan cara yang bermartabat, sebelum terlambat dengan luka penuh bebat". Dalam data (20), terdapat gaya bahasa aliterasi. Perulangan konsonan yang sama tergambar pada huruf konsonan " $\mathrm{t}$ " pada kata bermartabat, terlambat, dan bebat.

Data 21.

Papua tanpa duka bisa menjadi alat ukur

Sudahkah Indonesia makmur dengan cara yang betul?

Sebab pagi yang baru selalu dimulai dari arah timur

Jangan ada lagi rakyat Papua yang jatuh tersungkur

Data (21) diambil dari penggalan kalimat pada Catatan Najwa dengan tema "Nyala Papua". Pada data (21), terdiri dari empat kalimat yang berbentuk kalimat tunggal, karena masing-masing terdiri dari satu klausa, yaitu kalimat pertama "Papua tanpa duka bisa menjadi alat ukur", kalimat kedua "Sudahkah Indonesia makmur dengan cara yang betul?", kalimat ketiga "Sebab pagi yang baru selalu dimulai dari arah timur", kalimat keempat "Jangan ada lagi rakyat Papua yang jatuh tersungkur". Dalam data (21), terdapat gaya bahasa aliterasi. Perulangan konsonan yang sama tergambar pada huruf konsonan "r" pada kata ukur, makmur, cara, baru, arah, timur, rakyat, dan tersungkur.

Data 22.

Agenda pemberantasan korupsi mesti melejit cepat

Sebelum harta negara benar-benar habis disikat

Data (22) diambil dari penggalan kalimat pada Catatan Najwa dengan tema "Hidup Mati KPK". Pada data (22), terdiri dari satu kalimat yang berbentuk kalimat tunggal, karena terdiri satu klausa, yaitu "Agenda pemberantasan korupsi mesti melejit cepat sebelum harta negara benar-benar habis disikat". Dalam data (22), terdapat gaya bahasa aliterasi. Perulangan konsonan yang sama tergambar pada huruf konsonan "t" pada kata pemberantasan, mesti, melejit, cepat, harta, dan disikat. 
Data 23.

Yang pernah main mata dengan para perompak

Harus langsung dimasukkan ke dalam kotak

Data (23) diambil dari penggalan kalimat pada Catatan Najwa dengan tema "Hidup Mati KPK". Pada data (23), berbentuk kalimat tunggal, karena terdiri dari satu klausa, yaitu "Yang pernah main mata dengan para perompak harus langsung dimasukkan ke dalam kotak". Dalam data (23), terdapat gaya bahasa aliterasi. Perulangan konsonan yang sama tergambar pada huruf konsonan " $k$ " pada kata perompak, dimasukkan, ke, dan kotak.

\subsubsection{Asonansi}

Asonansi adalah semacam gaya bahasa yang berwujud perulangan bunyi vokal yang sama. Biasanya dipergunakan dalam puisi, kadang-kadang juga dalam prosa untuk memperoleh efek penekanan atau sekedar keindahan (Keraf, 2009:130).

Jenis gaya bahasa asonansi yang terdapat pada Catatan Najwa dapat dilihat di bawah ini.

Data 24.

Mereka bertanggung jawab dengan bekerja

Kita bertanggung jawab dengan awasi mereka

Data (24) diambil dari penggalan kalimat pada Catatan Najwa dengan tema "Penghuni Baru DPR". Pada data (24), berbentuk kalimat tunggal, karena terdiri dari satu klausa, yaitu "Mereka bertanggung jawab dengan bekerja, Kita bertanggung jawab dengan awasi mereka". Dalam data (24), terdapat gaya bahasa asonansi. Perulangan bunyi vokal yang sama tergambar pada huruf vokal "a" pada kata mereka, bekerja, kita, awasi, dan mereka.

Data 25.

Tokoh-tokoh politik bisa saja saling bertemu

Tapi politik belah bambu kadung menciptakan abu

Data (25) diambil dari penggalan kalimat pada Catatan Najwa dengan tema "Gerbang JokowiPrabowo: Siapa hendak turut?". Pada data (25), berbentuk kalimat majemuk setara, karena klausaklausanya memiliki status yang sama, dan ditandai dengan konjungsi koordinatif "tapi". Dalam data (25), terdapat gaya bahasa asonansi. Perulangan bunyi vokal yang sama tergambar pada huruf vokal "u" pada kata bertemu, bambu, kadung, dan abu. 
Data 26.

Rekonsiliasi tak bisa dijalin lewat seremoni

Mesti dibangun lewat praktik politik sehari-hari

Data 27.

Tak boleh ada kekuasaan yang tidak diawasi

Lakukan pengawasan tanpa agitasi dan provokasi

Data (26) dan (27) diambil dari penggalan kalimat pada Catatan Najwa dengan tema "Gerbang Jokowi-Prabowo: Siapa hendak turut?". Pada data (26), berbentuk kalimat tunggal, karena terdiri dari satu klausa, yaitu "Rekonsiliasi tak bisa dijalin lewat seremoni, mesti dibangun lewat praktik politik sehari-hari". Pada data (27), berbentuk kalimat tunggal, karena terdiri dari satu klausa, yaitu "Tak boleh ada kekuasaan yang tidak diawasi, lakukan pengawasan tanpa agitasi dan provokasi". Dalam data (26) dan (27), terdapat gaya bahasa asonansi. Perulangan bunyi vokal yang sama tergambar pada huruf vokal "i" pada kata rekonsiliasi, bisa, dijalin, seremoni, mesti, dibangun, praktik, politik, sehari-hari, tidak, diawasi, agitasi, dan provokasi.

Data 28.

Hukum akhirnya menjelma dokumen berdebu

Karena tak berbunyi laksana orang gagu

Data (28) diambil dari penggalan kalimat pada Catatan Najwa dengan tema "Sebelah Mata Novel Baswedan". Pada data (28), berbentuk kalimat majemuk bertingkat, ditandai dengan konjungsi subordinatif "karena". Dalam data (28), terdapat gaya bahasa asonansi. Perulangan bunyi vokal yang sama tergambar pada huruf vokal "u" pada kata hukum, dokumen, berdebu, berbunyi, dan gagu.

Data 29.

Di hadapan hukum semua harus setara

Jangan di pengadilan hasilnya malah berbeda

Data (29) diambil dari penggalan kalimat pada Catatan Najwa dengan tema "Kasta Hukuman". Pada data (29), terdiri dari dua kalimat. Kalimat pertama berbentuk kalimat bebas, karena ujarannya lengkap tanpa bantuan kalimat lain yang menjelaskannya, yaitu "Di hadapan hukum semua harus setara". Kalimat kedua berbentuk kalimat terikat, yaitu "Jangan di pengadilan hasilnya malah berbeda". Bukti keterikatan kalimat kedua dari kalimat pertama adalah adanya penanda anaforis — nya pada kata hasilnya, yang merujuk pada kata hukum dalam kalimat pertama. Dalam data (29), terdapat gaya bahasa 
asonansi. Perulangan bunyi vokal yang sama tergambar pada huruf vokal "a" pada kata hadapan, semua, harus, setara, jangan, pengadilan, hasilnya, malah, dan berbeda.

Data 30.

Sudah terlampau lama Papua menderita

Penghinaan fisik jelas tidak bisa diterima

Data (30) diambil dari penggalan kalimat pada Catatan Najwa dengan tema "Nyala Papua". Pada data (30), terdiri dari dua kalimat berbentuk kalimat tunggal, karena masing-masing terdiri dari satu klausa, yaitu kalimat pertama "Sudah terlampau lama Papua menderita" dan kalimat kedua "Penghinaan fisik jelas tidak bisa diterima". Dalam data (30), terdapat gaya bahasa asonansi. Perulangan bunyi vokal yang sama tergambar pada huruf vokal "a" pada kata sudah, lama, papua, menderita, penghinaan, jelas, tidak, bisa, dan diterima.

Data 31.

Kebhinekaan yang hakiki niscaya menoleransi

Perbedaan-perbedaan yang bersifat asali

Data 32.

Cara kekerasan menjauhkan kita dari demokrasi

Mata dibalas mata adalah jalan yang sungguh ngeri

Data (31) dan (32) diambil dari penggalan kalimat pada Catatan Najwa dengan tema "Nyala Papua". Pada data (31), berbentuk kalimat tunggal, karena hanya terdiri dari satu klausa, yaitu "Kebhinekaan yang hakiki niscaya menoleransi perbedaan-perbedaan yang bersifat asali". Pada data (32), terdiri dari dua kalimat berbentuk kalimat tunggal, karena masing-masing terdiri satu klausa, yaitu kalimat pertama "Cara kekerasan menjauhkan kita dari demokrasi" dan kalimat kedua "Mata dibalas mata adalah jalan yang sungguh ngeri". Dalam data (31) dan (32), terdapat gaya bahasa asonansi. Perulangan bunyi vokal yang sama tergambar pada huruf vokal "i" pada kata hakiki, niscaya, menoleransi, bersifat, asali, kita, dari, demokrasi, dibalas, dan ngeri.

Data 33.

Tataplah Papua sebagai karib yang setara

Perlakukanlah mereka selayaknya warga Negara 
Data (33) diambil dari penggalan kalimat pada Catatan Najwa dengan tema "Nyala Papua". Pada data (33), terdiri dari dua kalimat yang berbentuk kalimat tunggal, karena masing-masing hanya terdiri dari satu klausa, yaitu kalimat pertama "Tataplah Papua sebagai karib yang setara" dan kalimat kedua "Perlakukanlah mereka selayaknya warga Negara". Dalam data (33), terdapat gaya bahasa asonansi. Perulangan bunyi vokal yang sama tergambar pada huruf vokal "a" pada kata tataplah, papua, sebagai, karib, setara, mereka, selayaknya, warga, dan negara.

Data 34.

Ini bukan soal nila setitik rusak susu sebelanga

Karena melawan korupsi adalah perang tanpa jeda

Data (34) diambil dari penggalan kalimat pada Catatan Najwa dengan tema "Hidup Mati KPK". Pada data (34), berbentuk kalimat majemuk bertingkat, ditandai dengan adanya konjungsi subordinatif "karena". Dalam data (34), terdapat gaya bahasa asonansi. Perulangan bunyi vokal yang sama tergambar pada huruf vokal "a" pada kata bukan, soal, nila, rusak, sebelangga, karena, melawan, perang, tanpa, dan jeda.

\subsubsection{Pleonasme dan Tautologi}

Pada dasarnya pleonasme dan tautologi adalah acuan yang mempergunakan kata-kata lebih banyak daripada yang diperlukan untuk menyatakan satu pikiran atau gagasan (Keraf, 2009:133). Walaupun secara praktis kedua istilah itu disamakan saja, namun ada yang ingin membedakan keduanya. Suatu acuan disebut pleonasme bila kata yang berlebihan itu dihilangkan, artinya tetap utuh. Sebaliknya, acuan ini disebut tautologi kalau kata yang berlebihan itu sebenarnya mengandung perulangan dari sebuah kata yang lain (Keraf, 2009:133).

Jenis gaya bahasa pleonasme yang terdapat pada Catatan Najwa dapat dilihat di bawah ini.

Data 35.

Hentikan cemooh dan beragam bentuk penghinaan

Data (35) diambil dari penggalan kalimat pada Catatan Najwa dengan tema "Gerbang JokowiPrabowo: Siapa hendak turut?". Pada data (35), berbentuk kalimat tunggal, karena terdiri dari satu klausa, yaitu "Hentikan cemooh dan beragam bentuk penghinaan". Dalam data (35), terdapat gaya bahasa pleonasme, karena di dalam data tersebut terdapat bagian kalimat yang berlebihan, yaitu "dan beragam bentuk penghinaan". Walaupun bagian kalimat yang berlebihan tersebut dihilangkan, artinya tetap utuh. 
Data 36.

Hukum diciptakan agar tak ada kesewenangan

Supaya kita semua tak bertindak melampaui kepatutan

Data (36) diambil dari penggalan kalimat pada Catatan Najwa dengan tema "Kasta Hukuman". Pada data (36), berbentuk kalimat mejemuk bertingkat, ditandai dengan konjungsi "supaya", yaitu "Hukum diciptakan agar tak ada kesewenangan supaya kita semua tak bertindak melampaui kepatutan". Dalam data (36), terdapat gaya bahasa pleonasme, karena di dalam data tersebut terdapat bagian kalimat yang berlebihan, yaitu "supaya kita semua tak bertindak melampaui kepatutan". Walaupun bagian kalimat yang berlebihan tersebut dihilangkan, artinya tetap utuh.

Data 37.

Diskriminasi tidak pantas diberi tempat

Sudah sepatutnya rasisme juga dibabat

Data (37) diambil dari penggalan kalimat pada Catatan Najwa dengan tema "Nyala Papua". Pada data (37), terdiri dari dua kalimat yang berbentuk kalimat tunggal, karena masing-masing terdiri dari satu klausa, yaitu kalimat pertama "Diskriminasi tidak pantas diberi tempat" dan kalimat kedua "Sudah sepatutnya rasisme juga dibabat". Dalam data (37), terdapat gaya bahasa pleonasme, karena di dalam data tersebut terdapat kalimat yang berlebihan yaitu "Sudah sepatutnya rasisme juga dibabat". Walaupun kalimat yang berlebihan tersebut dihilangkan, artinya tetap utuh.

\subsubsection{Erotesis atau Pertanyaan Retoris}

Adalah semacam pertanyaan yang dipergunakan dalam pidato atau tulisan dengan tujuan untuk mencapai efek yang lebih mendalam dalam penekanan yang wajar, dan sama sekali tidak menghendaki adanya suatu jawaban, gaya ini biasanya dipergunakan sebagai salah satu alat yang efektif oleh para orator (Keraf, 2009:134). Dalam pertanyaan retoris terdapat asumsi bahwa hanya ada satu jawaban yang mungkin.

Jenis gaya bahasa erotesis atau pertanyaan retoris yang terdapat pada Catatan Najwa dapat dilihat di bawah ini.

Data 38.

Sudahkah Indonesia makmur dengan cara yang betul?

Data (38) diambil dari penggalan kalimat pada Catatan Najwa dengan tema "Nyala Papua". Pada data (38), berbentuk kalimat tunggal, karena terdiri dari satu klausa. Dalam data (38), terdapat gaya bahasa 
erotesis atau pertanyaan retoris, karena hanya ada satu jawaban yang mungkin dari kalimat pertanyaan pada data tersebut.

\subsubsection{Hiperbol}

Adalah semacam gaya bahasa yang mengandung suatu pernyataan yang berlebihan, dengan membesar-besarkan sesuatu hal (Keraf, 2009:135).

Jenis gaya bahasa hiperbol yang terdapat pada Catatan Najwa dapat dilihat di bawah ini.

Data 39.

Pemimpin bukanlah tahu bulat yang digoreng dadakan

Data (39) diambil dari penggalan kalimat pada Catatan Najwa dengan tema "Kejutan 2019". Pada data (39), berbentuk kalimat tunggal, karena terdiri dari satu klausa. Dalam data (39), terdapat gaya bahasa hiperbol. Pernyataan berlebihan itu tergambar pada klausa "bukanlah tahu bulat yang digoreng dadakan".

Data 40.

Tentang kebenaran yang terpojok sendirian

Perihal keadilan yang diperam kesunyian

Hukum akhirnya menjelma dokumen berdebu

Karena tak berbunyi laksana orang gagu

Data 41.

Kebenaran makin tenggelam di ruang yang pekat

Data 42.

Karena membiarkan banyak sengketa membatu

Data 43.

Teka-teki yang akhirnya menjelma hantu

Data (40), (41), (42) dan (43) diambil dari penggalan kalimat pada Catatan Najwa dengan tema "Sebelah Mata Novel Baswedan". Pada data (40), terdiri dari tiga kalimat. Pertama berbentuk kalimat tunggal, yaitu "Tentang kebenaran yang terpojok sendirian". Dalam kalimat tersebut terdapat gaya bahasa hiperbol. Pernyataan yang berlebihan itu tergambar pada bagian kalimat "kebenaran yang terpojok sendirian". Kedua berbentuk kalimat tunggal, yaitu "Perihal keadilan yang diperam kesunyian". Dalam kalimat tersebut terdapat gaya bahasa hiperbol. Pernyataan yang berlebihan itu 
tergambar pada bagian kalimat "keadilan yang diperam kesunyian". Ketiga berbentuk kalimat majemuk bertingkat, ditandai dengan konjungsi subordinatif karena, yaitu "Hukum akhirnya menjelma dokumen berdebu karena tak berbunyi laksana orang gagu". Dalam kalimat tersebut terdapat gaya bahasa hiperbol. Pernyataan yang berlebihan itu tergambar pada bagian kalimat "Hukum akhirnya menjelma dokumen berdebu" dan "tak berbunyi laksana orang gagu". Pada data (41), berbentuk kalimat tunggal, karena terdiri dari satu klausa, yaitu "Kebenaran makin tenggelam di ruang yang pekat". Dalam kalimat tersebut terdapat gaya bahasa hiperbol. Pernyataan yang berlebihan itu tergambar pada bagian kalimat "kebenaran makin tenggelam". Pada data (42), berbentuk kalimat tunggal, karena terdiri dari satu klausa, yaitu "Karena membiarkan banyak sengketa membatu". Dalam kalimat tersebut terdapat gaya bahasa hiperbol. Pernyataan yang berlebihan itu tergambar pada baggian kalimat "sengketa membatu". Pada data (43), berbentuk kalimat tunggal, karena terdiri dari satu klausa, yaitu "Teka-teki yang akhirnya menjelma hantu". Dalam kalimat tersebut terdapat gaya bahasa hiperbol. Pernyataan yang berlebihan itu tergambar pada bagian kalimat "menjelma hantu".

Data 44.

Pada yang lemah hukum justru menjadi buas

Data (44) diambil dari penggalan kalimat pada Catatan Najwa dengan tema "Kasta Hukuman". Pada data (44), berbentuk kalimat tunggal, karena terdiri dari satu klausa. Dalam data (44), terdapat gaya bahasa hiperbol. Pernyataan yang berlebihan itu tergambar pada kata "buas".

Data 45.

Jangan ada lagi rakyat Papua yang jatuh tersungkur

Data (45) diambil dari penggalan kalimat pada Catatan Najwa dengan tema "Nyala Papua". Pada data (45), berbentuk kalimat tunggal, karena terdiri dari satu klausa. Dalam data (45), terdapat gaya bahasa hiperbol. Pernyataan yang berlebihan itu tergambar pada bagian kalimat "jatuh tersungkur".

Data 46.

Karena melawan korupsi adalah perang tanpa jeda

Data 47.

Saat kinerja KPK kadung terkebiri 
Data (46) dan (47) diambil dari penggalan kalimat pada Catatan Najwa dengan tema "Hidup Mati KPK". Pada data (46), berbentuk kalimat tunggal, karena terdiri dari satu klausa, yaitu "Karena melawan korupsi adalah perang tanpa jeda". Dalam data (46), terdapat gaya bahasa hiperbol. Pernyataan yang berlebihan itu tergambar pada bagian kalimat "perang tanpa jeda". Pada data (47), berbentuk kalimat tunggal, karena terdiri dari satu klausa, yaitu "Saat kinerja KPK kadung terkebiri". Dalam data (47), terdapat gaya bahasa hiperbol. Pernyataan berlebihan itu tergambar pada kata "terkebiri".

\subsubsection{Persamaan atau Simile}

Adalah perbandingan yang bersifat eksplisit, maksudnya adalah bahwa ia langsung menyatakan sesuatu sama dengan hal yang lain. Untuk itu, ia memerlukan upaya yang secara eksplisit menunjukkan kesamaan itu, yaitu kata-kata: seperti, sama, sebagai, bagaikan, laksana, dan sebagainya (Keraf, 2009:138).

Jenis gaya bahasa simile yang terdapat pada Catatan Najwa dapat dilihat di bawah ini.

Data 48.

Karena tak berbunyi laksana orang gagu

Data (48) diambil dari penggalan kalimat pada Catatan Najwa dengan tema "Sebelah Mata Novel Baswedan". Pada data (48), berbentuk kalimat tunggal, karena terdiri dari satu klausa. Dalam data (48), terdapat gaya bahasa simile. Hal itu tergambar adanya kata "laksana" yang menunjukkan kesamaan antara "tak berbunyi" dengan "orang gagu".

\subsubsection{Personifikasi}

Adalah semacam gaya bahasa kiasan yang menggambarkan benda-benda mati atau barangbarang yang tidak bernyawa seolah-olah memiliki sifat kemanusiaan. Personifikasi (penginsanan) merupakan suatu corak khusus dari metafora, yang mengiaskan benda-benda mati bertindak, berbuat, berbicara, layaknya manusia (Keraf, 2009:140).

Jenis gaya bahasa personifikasi yang terdapat pada Catatan Najwa dapat dilihat di bawah ini.

Data 49.

Pada yang lemah hukum justru menjadi buas

Data (49) diambil dari penggalan kalimat pada Catatan Najwa dengan tema "Kasta Hukuman". Pada data (49), berbentuk kalimat tunggal, karena terdiri dari satu klausa. Dalam data (49), terdapat gaya bahasa personifikasi. Penginsanan itu tergambar pada kata "buas" yang seolah-olah hukum seperti manusia yang kejam dan bengis. 


\subsubsection{Sinekdoke}

Adalah suatu istilah yang diturunkan dari kata Yunani synekdechesthai yang berarti "menerima bersama-sama". Sinekdoke adalah semacam bahasa figuratif yang mempergunakan sebagian dari sesuatu hal untuk menyatakan keseluruhan (pars pro tato) atau mempergunakan keseluruhan untuk menyatakan sebagian (totum pro parte) (Keraf, 2009:142).

Jenis gaya bahasa sinekdoke yang terdapat pada Catatan Najwa dapat dilihat di bawah ini.

Data 50.

Masing-masing kubu saling intip dan saling kunci

Data (50) diambil dari penggalan kalimat pada Catatan Najwa dengan tema "Kejutan 2019". Pada data (50), berbentuk kalimat tunggal, karena terdiri satu klausa. Dalam data (50), terdapat gaya bahasa sinekdoke. Hal itu tergambar pada kata "masing-masing" yakni kata sebagian yang menyatakan keseluruhan.

\subsubsection{Metonimia}

Kata metonimia diturunkan dari kata Yunani meta yang berarti "menunjukkan perubahan", dan onoma yang berarti "nama". Dengan demikian, metonimia adalah suatu gaya bahasa yang mempergunakan sebuah kata untuk menyatakan suatu hal lain, karena mempunyai pertalian yang sangat dekat. Hubungan itu dapat berupa penemu untuk hasil penemuan, pemilik untuk barang yang dimiliki akibat untuk sebab, sebab untuk akibat, isi untuk menyatakan kulitnya, dan sebagainya (Keraf, 2009:142).

Jenis gaya bahasa metonimia yang terdapat pada Catatan Najwa dapat dilihat di bawah ini.

Data 51.

Pengawasan kepada wakil rakyat tak boleh kendor

Data (51) diambil dari penggalan kalimat pada Catatan Najwa dengan tema "Penghuni Baru DPR". Pada data (51), berbentuk kalimat tunggal, karena terdiri dari satu klausa. Dalam data (51), terdapat gaya bahasa metonimia. Menyatakan suatu hal lain tergambar pada kata "kendor/kendur" yang menggambarkan untuk menyatakan melemah (tentang pengawasan).

Data 52.

Sejarah kita disesaki cerita-cerita gelap

Data 53.

Pengungkapan yang dihalangi tabir kasak-kusuk 
Data 54.

Tentang kebenaran yang terpojok sendirian

Perihal keadilan yang diperam kesunyian

Data 55.

Kebenaran makin tenggelam di ruang yang pekat

Data 56.

Teka-teki yang akhirnya menjelma hantu

Data (52), (53), (54), (55), dan (56) diambil dari penggalan kalimat pada Catatan Najwa dengan tema "Sebelah Mata Novel Baswedan". Pada data (52), berbentuk kalimat tunggal, karena terdiri dari satu klausa, yaitu "Sejarah kita disesaki cerita-cerita gelap". Dalam data (52), terdapat gaya bahasa metonimia. Menyatakan suatu hal lain tergambar pada sebuah kata "gelap" yang menggambarkan untuk menyatakan tidak atau belum jelas, atau samar. Pada data (53), berbentuk kalimat tunggal, karena terdiri dari satu klausa, yaitu "Pengungkapan yang dihalangi tabir kasak-kusuk". Dalam data (53), terdapat gaya bahasa metonimia. Menyatakan suatu hal lain tergambar pada sebuah kata "kasak-kusuk" yang menggambarkan untuk menyatakan tidak terang-terangan atau tidak transparan. Pada data (54), terdiri dari dua kalimat yang berbentuk kalimat tunggal, karena masing-masing terdiri satu klausa, yaitu kalimat pertama "Tentang kebenaran yang terpojok sendirian" dan kalimat kedua "Perihal keadilan yang diperam kesunyian". Dalam data (54), terdapat gaya bahasa metonimia. Menyatakan suatu hal lain tergambar pada sebuah kata "terpojok" dan "diperam" yang menggambarkan untuk menyatakan sulitnya terungkap atau terbongkar. Pada data (55), berbentuk kalimat tunggal, karena terdiri dari satu klausa, yaitu "Kebenaran makin tenggelam di ruang yang pekat. Dalam data (55), terdapat gaya bahasa metonimia. Menyatakan suatu hal lain tergambar pada sebuah kata "tenggelam" yang menggambarkan untuk menyatakan hilang atau lenyap. Pada data (56), berbentuk kalimat tunggal, karena terdiri satu klausa, yaitu "Teka-teki yang akhirnya menjelma hantu". Dalam data (56), terdapat gaya bahasa metonimia. Menyatakan suatu hal lain tergambar pada sebuah kata "hantu" yang menggambarkan untuk menyatakan yang tak tampak atau tak terlihat.

Data 57.

Jangan sampai hukum malah tumpul ke atas

Pada yang lemah hukum justru menjadi buas 
Data (57) diambil dari penggalan kalimat pada Catatan Najwa dengan tema "Kasta Hukuman". Pada data (57), berbentuk kalimat tunggal, karena terdiri satu klausa, yaitu "Jangan sampai hukum malah tumpul ke atas, pada yang lemah hukum justru menjadi buas". Dalam data (57), terdapat gaya bahasa metonimia. Menyatakan suatu hal lain tergambar pada kata "tumpul" dan "buas" yang menggambarkan untuk menyatakan ketidakadilan.

Data 58.

Jangan ada lagi rakyat Papua yang jatuh tersungkur

Data (58) diambil dari penggalan kalimat pada Catatan Najwa dengan tema "Nyala Papua". Pada data (58), berbentuk kalimat tunggal, karena terdiri dari satu klausa, yaitu "Jangan ada lagi rakyat Papua yang jatuh tersungkur". Dalam data (58), terdapat gaya bahasa metonimia. Menyatakan suatu hal lain tergambar pada sebuah kata "tersungkur" yang menggambarkan untuk menyatakan penderitaan.

Data 59.

Sebelum harta negara benar-benar habis disikat

Data 60.

Saat kinerja KPK kadung terkebiri

Data 61.

Yang menghalangi pemberantasan korupsi harus disikat

Data (59), (60), dan (61) diambil dari penggalan kalimat pada Catatan Najwa dengan tema "Hidup Mati KPK". Pada data (59), berbentuk kalimat tunggal, karena terdiri dari satu klausa, yaitu "Sebelum harta negara benar-benar habis disikat". Dalam data (59), terdapat gaya bahasa metonimia. Menyatakan suatu hal lain tergambar pada sebuah kata "disikat" yang menggambarkan untuk menyatakan diberantas. Pada data (60), berbentuk kalimat tunggal, karena terdiri dari satu klausa, yaitu "Saat kinerja KPK kadung terkebiri". Dalam data (60), terdapat gaya bahasa metonimia. Menyatakan suatu hal lain tergambar pada sebuah kata "terkebiri" yang menggambarkan untuk menyatakan hilangnya identitas. Pada data (61), berbentuk kalimat tunggal, karena terdiri dari satu klausa, yaitu "Yang menghalangi pemberantasan korupsi harus disikat". Dalam data (61), terdapat gaya bahasa metonimia. Menyatakan suatu hal lain tergambar pada sebuah kata "disikat" yang menggambarkan untuk menyatakan disingkirkan. 


\subsubsection{Sarkasme}

Sarkasme merupakan suatu acuan yang lebih kasar dari ironi dan sinisme. Ia adalah suatu acuan yang mengandung kepahitan dan celaan yang getir. Sarkasme dapat saja bersifat ironis, dapat juga tidak, tetapi yang jelas adalah bahwa gaya ini selalu akan menyakiti hati dan kurang enak didengar. Kata sarkasme diturunkan dari kata Yunani sarkasmos yang lebih jauh diturunkan dari kata kerja sakasein yang berarti "merobek-robek daging seperti anjing", "menggigit bibir karena marah", atau "berbicara dengan kepahitan" (Keraf, 2009:144).

Jenis gaya bahasa sarkasme yang terdapat pada Catatan Najwa dapat dilihat di bawah ini.

\section{Data 62.}

Karena kandidat seharusnya bukan hasil dagang eceran

Pemimpin bukanlah tahu bulat yang digoreng dadakan

Data (62) diambil dari penggalan kalimat pada Catatan Najwa dengan tema "Kejutan 2019". Pada data (62), terdiri dari dua kalimat berbentuk kalimat tunggal, karena masing-masing terdiri dari satu klausa, yaitu kalimat pertama "Karena kandidat seharusnya bukan hasil dagang eceran", dan kalimat kedua "Pemimpin bukanlah tahu bulat yang digoreng dadakan". Dalam data (62), terdapat gaya bahasa sarkasme. Sebuah cemooh dan ejekan tergambar pada bagian kalimat "bukan hasil dagang eceran" dan "bukanlah tahu bulat yang digoreng dadakan" yang menggambarkan sindiran untuk seorang calon atau kandidat pemimpin yang akan dimajukan harus benar-benar matang dan siap memimpin.

Data 63.

Cerita tak enak kadung lekat kepada wakil rakyat

Data 64.

Kepercayaan yang kita berikan harus dijaga

Jangan sampai dipakai menggarong uang negara

Kinerja buruk periode lama harus diperbaiki

Jangan cuma sibuk dengan intrik politik setiap hari

Data (63) dan (64) diambil dari penggalan kalimat pada Catatan Najwa dengan tema "Penghuni Baru DPR". Pada data (63), berbentuk kalimat tunggal, karena terdiri dari satu klausa, yaitu "Cerita tak enak kadung lekat kepada wakil rakyat". Pada data (64), terdiri dari empat kalimat yang berbentuk kalimat tunggal, karena masing-masing terdiri dari satu klausa. Dalam data (63) dan (64), terdapat gaya bahasa sarkasme. Sebuah cemooh dan ejekan tergambar pada bagian kalimat "cerita tak enak", "jangan 
sampai dipakai menggarong uang negara", "kinerja buruk periode lama harus diperbaiki", dan "jangan cuma sibuk dengan intrik politik setiap hari", yang menggambarkan sindiran disampaikan kepada kinerja para wakil rakyat yang masih buruk.

Data 65.

PLN tak bisa lepas tanggung jawab begitu saja

Para petingginya tak bisa buang badan seenaknya

Data (65) diambil dari penggalan kalimat pada Catatan Najwa dengan tema "Hidup Mati Listrik". Pada data (65), terdiri dari dua kalimat yang berbentuk kalimat tunggal, karena masing-masing terdiri satu klausa, yaitu kalimat pertama "PLN tak bisa lepas tanggung jawab begitu saja" dan kalimat kedua "Para petingginya tak bisa buang badan seenaknya". Dalam data (65), terdapat gaya bahasa sarkasme. Sebuah cemooh dan ejekan tergambar pada bagian kalimat "tak bisa lepas tanggung jawab begitu saja" dan "tak bisa buang badan seenaknya", yang menggambarkan sindiran disampaikan kepada para pejabat PLN yang menyelamatkan diri sendiri atau lepas tanggung jawab dari sebuah masalah yang terjadi.

Data 66.

Jangan disusupi oleh orang-orang yang nakal

Data (66) diambil dari penggalan kalimat pada Catatan Najwa dengan tema "Hidup Mati KPK". Pada data (66), berbentuk kalimat tunggal, karena terdiri dari satu klausa, yaitu "Jangan disusupi oleh orang-orang yang nakal". Dalam data (66), terdapat gaya bahasa sarkasme. Hal itu tergambar pada bagian kalimat "disusupi oleh orang-orang yang nakal" yang menggambarkan sindiran disampaikan kepada calon pimpinan KPK yang baru.

\section{KESIMPULAN DAN SARAN}

Catatan Najwa, sebuah penutup acara yang berisikan narasi dari seorang jurnalis senior yang mampu membuat pembaca dan pendengarnya terkesima dan terpancing untuk mencerna dan memikirkan lebih seksama. Bukan hanya sekedar goresan kata-kata, melainkan sikap dan kejelian dalam mengolah kata dan rasa. Setiap barisan kalimatnya mengandung sindiran dengan gaya bahasa dan makna yang tersirat. Selain itu, gaya bahasa pada Catatan Najwa berperan mempertegas dan memperindah kalimat sehingga indah dan menarik bagi pendengar dan pembaca. Penggunaan gaya bahasa menjadi faktor penting oleh Najwa Shihab dan berhasil menarik para pendengar dan pembacanya. Akan tetapi penggunaan gaya bahasa dalam Catatan Najwa akan sulit dipahami oleh pendengar atau pembaca yang kurang memiliki kompetensi berbahasa. Dari pengamatan yang telah dilakukan, maka dari itu penulis menyimpulkan penjelasan tersebut. 
Pertama, terdapat tiga jenis gaya bahasa berdasarkan struktur kalimat pada Catatan Najwa di Trans 7 edisi bulan Juli - Agustus 2019. Ketiga jenis gaya bahasa tersebut yaitu paralelisme, antitesis, dan repetisi.

Kedua, terdapat sepuluh jenis gaya bahasa berdasarkan langsung dan tidaknya makna pada Catatan Najwa di Trans 7 edisi bulan Juli - Agustus 2019. Sepuluh jenis gaya bahasa tersebut yaitu aliterasi, asonansi, pleonasme \& tautologi, erotesis atau pertanyaan retoris, hiperbol, persamaan atau simile, personifikasi, sinekdoke, metonimia, dan sarkasme.

\section{DAFTAR PUSTAKA}

Chaer, Abdul. 2012. Linguistik Umum, Jakarta: Rineka Cipta

Chaer, Abdul. 2009. Pengantar Semantik Bahasa Indonesia, Jakarta: PT Asdi Mahasatya

Heru, Agus. 2018. "Gaya Bahasa Sindiran Ironi, Sinisme, dan Sarkasme dalam Berita Utama Harian Kompas" dalam Jurnal Pembahsi. Vol.8 Nomor 2

Keraf, Gorys. 2009. Diksi dan Gaya Bahasa, Jakarta: PT. Gramedia Pustaka Utama

Mariyawati, Mery. 2015. "Penggunaan Diksi dan Gaya Bahasa Najwa Shihab pada Acara Mata Najwa di Metro TV". Jember: Skripsi Strata 1 Program Studi Sastra Indonesia Universitas Jember

Peleger, Zul Fahmy. 2018. "Gaya Bahasa Dalam Lirik-Lirik lagu Linkin Park Album A Thousand Suns" dalam Jurnal Elektronik Fakultas Sastra Universitas Sam Ratulangi. Vol.3 Nomor 2

Ramadhani, Sry Elly dan Hariadi dan Taufik Hidayat. 2019. "Analisis Gaya Bahasa Kiasan Dalam Kumpulan Cerpen Red Jewel Of Soul Karya Sinta Yudisia" dalam Jurnal Samudra Bahasa. Vol.2 Nomor 1

Ramadhianto, Nur Rizky Maghfur. 2019. "Telaah Gaya Bahasa Puisi Pada Akun Instagram @PUISILANGIT. Malang: Skripsi Strata 1 Program Studi Pendidikan Bahasa dan Sastra Indonesia Universitas Muhammadiyah Malang

Ratna, Nyoman Kutha. 2009. Stilistika: Kajian Puitika Bahasa, Sastra, dan Budaya, Yogyakarta: Pustaka Pelajar

Sudaryanto. 2015. Metode dan Aneka Teknik Analisis Bahasa, Yogyakarta: Sanata Dharma University Press

Sugiyono. 2016. Metode Penelitian; Kuantitatif, Kualitatif, dan R\&D, Bandung: ALFABETA

Susanto, Emi. 2013. "Analisis Gaya Bahasa Novel Anak Sejuta Bintang Karya Akmal Nasery Basral". Tanjung Pinang: Artikel E-Journal Jurusan Pendidikan Bahasa dan Sastra Indonesia Universitas Maritim Raja Ali Haji 